\title{
Effect of the Levels of Minerals, Phytohormones and Pistil Extracts on In Vitro Ovule Development and Pollen Tube Growth in Excised Grape Pistils
}

\author{
Goro Okamoto and Naoki Omori \\ Faculty of Agriculture, Okayama University, Tsushima, Okayama 700
}

\begin{abstract}
Summary
The poor set of normal seeded berries in 'Pione' grapes is attributed to the small number of fertilized eggs in the ovules. To examine the effect of nutrients and phytohormones on ovule development and pollen tube growth, young florets, about one week before bloom, were cultured in vitro on several media. Florets of 'Muscat of Alexandria', which is known to be a good setting cultivar, were cultured for comparison.

The ovary size became larger in both cultivars as the concentration of inorganic components of Nitsch and MS media or only $\mathrm{KNO}_{3}$ of the Nitsch medium was increased. Ovule development and pollen tube growth, however, were inhibited in these enlarged ovaries, especially in 'Pione' pistils. The addition of $1 \sim 10$ ppm NAA, GA or BA to the Nitsch medium inhibited ovule development and pollen tube growth in pistils of 'Pione', but we observed no significant change in ovary size. Pollen tube growth was inhibited in pistils of 'Muscat of Alexandria' cultured on medium containing water extracts of 'Pione' pistils; however, ovary growth and ovule development were not affected.

From these results, we concluded that in florets of 'Pione', an excess of nitrogenous nutrients leads to severe inhibition of ovule development and pollen tube growth. Pollen tube growth inhibitors, detected abundantly in 'Pione' pistil extracts, do not appear to be inorganic or hormonal substances.
\end{abstract}

\section{Introduction}

Tetraploid grape cultivars, such as 'Kyoho' ( $V i$ tis vinifera $\times V$. labruscana) and 'Pione' ('Kyoho' $\times V$. vinifera), often fail to set a sufficient number of seeded berries to form an acceptable cluster size. Flower clusters born on a vigorous shoot usually result in severe flower shatter or in the production of many small-sized seedless berries $(14,15)$. The causes of such poor set in these tetraploid grapes are mainly: 1) the development of imperfect ovules and 2) the inhibition of pollen tube growth in the pistils $(15,16,17)$. The percentage of normal ovules is less in pistils borne on vigorous shoots than that borne on weaker ones (16). Pollen tube entry into ovules is improved by prebloom SADH treatments which increases the number of seeded berries per cluster $(9,10)$. These results suggest that the nutritional or hormonal

Received for publication 28 March 1991. condition of the shoot or flower cluster has a great influence on ovule development and pollen tube growth in tetraploid grape pistils. Pistils of tetraploid grapes, on the other hand, contain a high level of pollen tube growth inhibitors that severely inhibit both pollen germination and tube growth on agar media $(18,19)$, though those inhibitors are not yet identified.

In this paper, we cultured prebloom grape pistils on several media to clarify the effects of nutritional and hormonal conditions on both ovule development and pollen tube growth in pistils.

\section{Materials and Method}

Flower clusters from mature vines of 'Pione' and 'Muscat of Alexandria' were sampled about one week before anthesis. Several branches of the cluster were cut off, wrapped in a small piece of gauze and dipped into a $5 \%$ sodium hypochloride solution for $5 \mathrm{~min}$ to ensure sterilization. After washing with sterilized water 3 times, each floret 
was cut off at the base of the pedicel.

To determine the suitable culture media for grape pistils, basal media of White (20), Nitsch (12) and Murashige \& Skoog (8) were tested at double, original and half strength. Each medium was adjusted to $\mathrm{pH} 5.5$ with $0.1 \mathrm{~N}-\mathrm{NaOH}$, and added with $50 \mathrm{~g} /$ liter of sucrose and $5 \mathrm{~g} / \mathrm{liter}$ of agar. In another test series, only the level of $\mathrm{KNO}_{3}$ of Nitsch medium was modified. Each medium was sterilized by autoclaving at $110^{\circ} \mathrm{C}$ for $15 \mathrm{~min}$. Phytohormones such as $\alpha$-naphthalene acetic acid (NAA), gibberellic acid (GA) and 6-benzylaminopurine $(\mathrm{BA})$ were sterilized by filtering them through a $22 \mu \mathrm{m}$ membrane filter (Millexas filter) and then added to the autoclaved medium. Each medium was dispensed in $10 \mathrm{ml}$ aliquots into plastic petri dishes $(\phi 50 \times 13 \mathrm{~mm})$. Five grams of mature pistils of 'Pione' and 'Muscat of Alexandria' were homogenized with $10 \mathrm{ml}$ of distilled water, and the mixture was centrifuged at $10,000 \times \mathrm{g}$ for $30 \mathrm{~min}$. The volume of the supernatant was brought to $50 \mathrm{ml}$ with distilled water. Twenty $\mathrm{ml}$ of the crude extracts were lyophilized and extracted successively with $10 \mathrm{ml}$ of hexane, ethyl acetate, ethanol and $\mathrm{H}_{2} \mathrm{O}$ at $40^{\circ} \mathrm{C}$ for $30 \mathrm{~min}$. Extraction was carried out 3 times for each step. Each extract was evaporated to dryness and then suspended with $20 \mathrm{ml}$ of methanol. Five-, 2-, and 1- $\mathrm{ml}$ aliquots of each sample were dried in an evaporator at $40^{\circ} \mathrm{C}$. The residue was redissolved in $0.5 \mathrm{ml}$ of methanol which was added to $10 \mathrm{ml}$ of half-strength MS medium.

Fifteen florets of 'Pione' and 'Muscat of Alexandria' grapes were embedded in each petri dish under aseptic conditions. Three dishes for each test were incubated at $25^{\circ} \mathrm{C}$ under $3 \mathrm{Klx}$ of light intensity for $16 \mathrm{hr}$ per day. Pistils that bloomed 5 to 7 days after incubation were pollinated with pollen of 'Muscat of Alexandria' and then tranferred into a sterile dish containing the same medium as previously cultured. Sampling of these pistils was made 3 days after pollination.

After measuring ovary size, pistils were fixed with FAA, dehydrated with EtOH-BuOH series, and embedded into paraffin blocks. Fifteen pistils were sliced into longitudinal sections of $15 \mu \mathrm{m}$ thick and stained with alcian blue and Shiff's solution. Developmental stages of ovules were classified under a microscope into 6 categories as shown in a previous report (15). The ovary walls of another 15 pistils were trimmed with a razor blade, leaving the stigma and placental tissue intact. The pistils were then softened by soaking them in $1 \mathrm{~N}-\mathrm{NaOH}$ at $50^{\circ} \mathrm{C}$ for $2 \sim 5 \mathrm{~min}$. After they were washed with distilled water, the samples were mounted on a slide glass with water soluble aniline blue, and squashed with a slide cover glass. The number of pollen tubes reaching the style, ovary and micropyle was counted under an epifluorescence microscope.

\section{Results}

\section{Effect of basal media on ovary growth, ovule de- velopment and pollen tube growth}

Both 'Pione' and 'Muscat of Alexandria' pistils cultured on MS and Nitsch media grew larger than those cultured on White medium. Increased strength of the medium resulted in larger pistil size. Ovary size measured 3 days after pollination is shown in Table 1. The effect of the strength of the medium on ovary size was more noticeable in 'Pione' than in 'Muscat of Alexandria' cultivars. Ovary size was also augmented by increasing the $\mathrm{KNO}_{3}$ concentration of the basal medium of Nitsch, especially in 'Pione' pistils.

A high percentage of imperfect ovules such as those with unformed or undeveloped embryo sac was found in 'Pione' pistils cultured on double strength media of Nitsch and of MS (Table 2). Such imperfect ovules were also found frequently in 'Pione' pistils cultured on the modified medium of Nitsch where the $\mathrm{KNO}_{3}$ concentration was doubled (Data not shown).

The extent of pollen tube penetration into each part of the pistil is shown in Table 3. Tube growth into ovaries was greatly inhibited in 'Pione' pistils cultured on double strength media. A similar trend was also observed on modified medium of Nitsch containing different concentration of $\mathrm{KNO}_{3}$ (Data not shown).

\section{Effect of phytohormones on ovary growth, ovule development and pollen tube growth}

No relationship could be established between ovary size and the level of GA, BA and NAA added to the Nitsch media in either cultivar. Ovule development in 'Pione' pistils, however, was inhibited when more than $1 \mathrm{ppm}$ of NAA or $10 \mathrm{ppm}$ 
Table 1. Ovary size of 'Pione' and 'Muscat of Alexandria' pistils grown on different basal media”.

\begin{tabular}{|c|c|c|c|c|c|}
\hline \multirow[b]{2}{*}{ Medium } & & \multicolumn{2}{|c|}{ Ovary diameter (mm) } & \multicolumn{2}{|c|}{ Ovary length (mm) } \\
\hline & & Pione & $\begin{array}{l}\text { Muscat of } \\
\text { Alexandria }\end{array}$ & Pione & $\begin{array}{l}\text { Muscat of } \\
\text { Alexandria }\end{array}$ \\
\hline \multicolumn{6}{|l|}{ Whilte } \\
\hline$\times 2$ & & $1.60 \mathrm{c}$ & $1.61 \mathrm{c}$ & $1.61 \mathrm{c}$ & $1.50 \mathrm{c}$ \\
\hline$\times 1$ & & $1.68 \mathrm{c}$ & $1.53 \mathrm{c}$ & $1.65 \mathrm{c}$ & $1.56 \mathrm{c}$ \\
\hline$\times 1 / 2$ & & $1.60 \mathrm{c}$ & $1.58 \mathrm{c}$ & $1.68 \mathrm{c}$ & $1.52 \mathrm{c}$ \\
\hline \multicolumn{6}{|l|}{ Nitsch } \\
\hline$\times 2$ & & $2.80 \mathrm{a}$ & $2.23 \mathrm{a}$ & $2.91 \mathrm{a}$ & $2.45 \mathrm{a}$ \\
\hline \multicolumn{6}{|l|}{$\times 1$} \\
\hline $\mathrm{KNO}_{3}$ & $\times 2$ & $2.78 \mathrm{a}$ & $2.18 \mathrm{a}$ & $2.93 \mathrm{a}$ & $2.13 \mathrm{a}$ \\
\hline & $\times 1$ & $2.42 \mathrm{~b}$ & $1.93 \mathrm{~b}$ & $2.68 \mathrm{ab}$ & $2.00 \mathrm{ab}$ \\
\hline & $\times 1 / 2$ & $2.21 \mathrm{~b}$ & $1.85 \mathrm{~b}$ & $1.88 \mathrm{bc}$ & $1.68 \mathrm{bc}$ \\
\hline & $\times 0$ & $1.61 \mathrm{c}$ & $1.56 \mathrm{c}$ & $1.63 \mathrm{c}$ & $1.51 \mathrm{c}$ \\
\hline$\times 1 / 2$ & & $1.96 \mathrm{bc}$ & $1.71 \mathrm{c}$ & $2.23 \mathrm{~b}$ & $1.80 \mathrm{~b}$ \\
\hline \multicolumn{6}{|l|}{ MS } \\
\hline$\times 2$ & & $2.89 \mathrm{a}$ & $2.41 \mathrm{a}$ & $2.98 \mathrm{a}$ & $2.56 \mathrm{a}$ \\
\hline$\times 1$ & & $2.56 \mathrm{ab}$ & $2.04 \mathrm{ab}$ & $2.89 \mathrm{a}$ & $2.23 \mathrm{ab}$ \\
\hline$\times 1 / 2$ & & $2.30 \mathrm{~b}$ & $1.91 \mathrm{~b}$ & $2.56 \mathrm{ab}$ & $2.10 \mathrm{ab}$ \\
\hline
\end{tabular}

" Each medium contained $50 \mathrm{~g} /$ liter of sucrose and $5 \mathrm{~g} /$ liter of agar. Ten to 15 ovaries were examined. Means were compared by t-test. Non-significant means $(P>0.01)$ have the same letter in each column.

Table 2. Ovule development in the pistil of 'Pione' and 'Muscat of Alexandria' grapes grown on different basal media".

\begin{tabular}{|c|c|c|c|c|c|c|}
\hline \multirow{2}{*}{$\begin{array}{l}\text { Medium and } \\
\text { strength }\end{array}$} & \multicolumn{6}{|c|}{$\%$ of total ovules examined ${ }^{y}$} \\
\hline & $\begin{array}{l}\text { Imperfect } \\
\text { integument }\end{array}$ & $\begin{array}{l}\text { Without } \\
\text { embryo sac }\end{array}$ & $\begin{array}{c}2 \text { or } 4 \\
\text { nucleate }\end{array}$ & $\begin{array}{l}\text { Unfused polar } \\
\text { nuclei }\end{array}$ & $\begin{array}{l}\text { Imperfect egg } \\
\text { apparatus }\end{array}$ & Normal \\
\hline \multicolumn{7}{|c|}{ Pione } \\
\hline \multicolumn{7}{|l|}{ Nitsh } \\
\hline$\times 2$ & 1.7 & 41.7 & 25.0 & 1.7 & 5.0 & 23.3 \\
\hline$\times 1$ & 3.3 & 16.4 & 14.7 & 4.9 & 1.6 & 59.0 \\
\hline$\times 1 / 2$ & 8.2 & 29.5 & 16.4 & 3.3 & 3.3 & 39.3 \\
\hline \multicolumn{7}{|l|}{ MS } \\
\hline$\times 2$ & 4.8 & 50.0 & 19.4 & 8.1 & 9.7 & 8.1 \\
\hline$\times 1$ & 8.1 & 38.7 & 24.2 & 3.2 & 6.5 & 19.4 \\
\hline$\times 1 / 2$ & 0.0 & 20.6 & 12.7 & 6.3 & 9.5 & 50.8 \\
\hline \multicolumn{7}{|c|}{ Muscat of Alexandria } \\
\hline \multicolumn{7}{|l|}{ Nitsch } \\
\hline$\times 2$ & 0.0 & 25.3 & 23.6 & 3.4 & 3.4 & 34.4 \\
\hline$\times 1$ & 1.6 & 15.9 & 14.3 & 7.9 & 9.5 & 50.8 \\
\hline$\times 1 / 2$ & 3.3 & 18.3 & 16.7 & 3.3 & 5.0 & 53.3 \\
\hline \multicolumn{7}{|l|}{ MS } \\
\hline$\times 2$ & 0.0 & 41.9 & 12.9 & 4.8 & 8.1 & 32.3 \\
\hline$\times 1$ & 0.0 & 25.0 & 30.0 & 3.3 & 3.3 & 38.3 \\
\hline$\times 1 / 2$ & 1.6 & 27.0 & 15.9 & 0.0 & 0.0 & 55.6 \\
\hline
\end{tabular}

"Each medium contained $50 \mathrm{~g} /$ liter of sucrose and $5 \mathrm{~g} /$ liter of agar.

" Fifty to 60 ovules in 15 ovaries were examined for each treatment. 
Table 3. Pollen tube growth in the pistil of 'Pione' and 'Muscat of Alexandria' grapes grown on different basal media'.

\begin{tabular}{|c|c|c|c|c|c|c|}
\hline \multirow{3}{*}{$\begin{array}{l}\text { Medium and } \\
\text { strength }\end{array}$} & \multicolumn{6}{|c|}{ Mean number of pollen tubes per pistil ${ }^{y}$} \\
\hline & \multicolumn{2}{|c|}{ Style } & \multicolumn{3}{|c|}{ Ovary } & \multirow{2}{*}{ Micropyle } \\
\hline & Upper & Middle & Upper & Middle & Bottom & \\
\hline \multicolumn{7}{|c|}{ Pione } \\
\hline \multicolumn{7}{|l|}{ Nitsch } \\
\hline$\times 2$ & $8.9(8)$ & $1.5(2)$ & - & - & - & - \\
\hline$\times 1$ & $12.3(10)$ & $4.6(6)$ & $2.0(3)$ & $1.0(1)$ & - & - \\
\hline$\times 1 / 2$ & $15.2(12)$ & $3.2(8)$ & $2.6(4)$ & $1.0(1)$ & - & - \\
\hline \multicolumn{7}{|l|}{ MS } \\
\hline$\times 2$ & $6.5(5)$ & - & - & - & - & - \\
\hline$\times 1$ & $8.0(7)$ & $1.0(1)$ & $1.0(1)$ & - & - & - \\
\hline$\times 1 / 2$ & $10.5(9)$ & $2.0(2)$ & $1.5(2)$ & $1.0(1)$ & - & - \\
\hline \multicolumn{7}{|c|}{ Muscat of Alexandria } \\
\hline \multicolumn{7}{|l|}{ Nitsch } \\
\hline$\times 2$ & $10.5(10)$ & $3.2(5)$ & - & - & - & - \\
\hline$\times 1$ & $25.0(14)$ & $9.0(10)$ & $3.3(6)$ & $2.0(2)$ & $1.0(1)$ & $1.0(1)$ \\
\hline$\times 1 / 2$ & $28.5(15)$ & $8.6(11)$ & $2.3(4)$ & $2.5(2)$ & $1.0(2)$ & $1.0(2)$ \\
\hline \multicolumn{7}{|l|}{ MS } \\
\hline$\times 2$ & $15.8(12)$ & $4.0(5)$ & - & - & - & - \\
\hline$\times 1$ & $18.5(14)$ & $8.3(9)$ & $2.5(3)$ & $1.5(2)$ & $1.0(2)$ & $1.0(1)$ \\
\hline$\times 1 / 2$ & $35.1(13)$ & $10.5(10)$ & $1.3(3)$ & $1.0(1)$ & - & - \\
\hline
\end{tabular}

" Each contained $50 \mathrm{~g} /$ liter of sucrose and $5 \mathrm{~g} /$ liter of agar.

$"$ Mean numbers only for the pistils in which pollen tubes reached. Figures in parentheses represent the number of pistils reached by pollen tubes among 15 pistils examined. - shows no pollen tube was found.

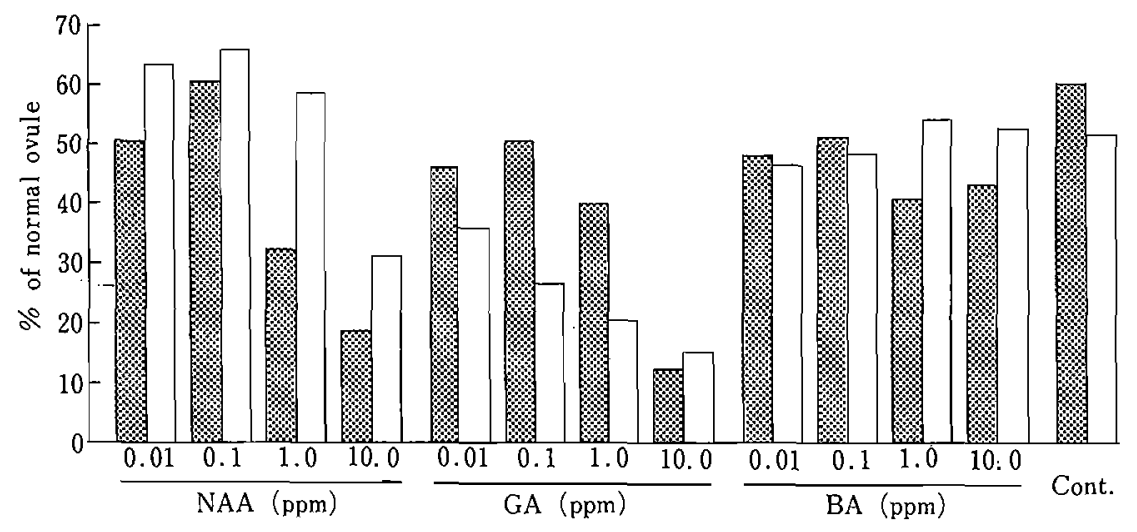

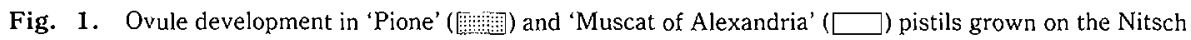
media containing different levels of phytohormones. Each medium contained $50 \mathrm{~g} / \mathrm{liter}$ of sucrose and $5 \mathrm{~g} /$ liter of agar. Fifty to 60 ovules in 15 ovaries were examined.

of GA were added to the medium (Fig. 1). Immature ovules such as those with a 2- and 4-nucleate embryo sacs or without an embryo sac were found more frequently in these media. Inhibition of ovule development in 'Muscat of Alexandria' pistils was observed after the addition of $10 \mathrm{ppm}$ of NAA or more than $0.1 \mathrm{ppm}$ of GA. Pollen tube growth was severely inhibited in the medium containing $10 \mathrm{ppm}$ of NAA or more than $1 \mathrm{ppm}$ of $\mathrm{BA}$ for 'Pione' (Table 4). The medium with more than $1 \mathrm{ppm}$ of NAA or GA, or more than $0.1 \mathrm{ppm}$ of $\mathrm{BA}$ for 'Muscat of Alexandria' also had an inhibitory ef- 
fect (Data not shown).

\section{Effect of pistil extracts on ovary growth, ovule de- velopment and pollen tube growth}

Ovary growth and ovule development in the pistils of both cultivars were not affected by the addition of pistil extracts of either cultivar (Data not shown). No morphological change was observed in the stigma or conductive tissue (central axis of a style through which pollen tubes pass) in either cultivar. Pollen tube growth in pistils of both cultivars, however, was greatly inhibited by adding extracts of 'Pione' pistils (Fig. 2). The addition of pistil extracts of 'Muscat of Alexandria' did not severely affect either cultivar (Table 5).

Examinations of fractionated extracts by successive extractions with several organic solvents revealed that the ethanolic and water extracts contained the major inhibitors (Table 6).

\section{Discussion}

Basal media of both Nitsch and MS were found to be suitable for the culture of grape florets. Ovary cultures of cucumber and tomatoes (12) and 'Delaware' grapes (3) on Nitsch medium have given significant results. MS medium has been used successfully in the cultivation of strawberry receptacles (4) and in the ovules of Brassica (2). White medium resulted in poor pistil growth. We propose that the high sodium and sulphur content of White medium affects pistil growth.

The florets, cultured in vitro, bloomed earlier than did those of the mother plant in the greenhouse. Temperature may be the main factor for this difference, as the culture room is a constant $25^{\circ} \mathrm{C}$, whereas at night the temperature in the plastic house falls to $12^{\circ} \sim 15^{\circ} \mathrm{C}$ and to $18^{\circ} \sim 20^{\circ} \mathrm{C}$ in the greenhouse, even with internal heating. Kobayashi et al. (5) found that night temperature influences the time of blooming.

For both 'Pione' and 'Muscat of Alexandria', high concentrations of mineral nutrients, especially nitrogenous compounds, resulted in larger ovaries. This indicates that a supply of inorganic nutrients is necessary for pistil growth. The effect of this supply was more apparent on 'Pione' than on 'Muscat of Alexandria', suggesting that 'Pione' grape vine is more sensitive to nutritional conditions. However, it was found that the high concentration of inorganic nutrients had an opposite effect on the development of ovules. In most cases, the development of the embryo sac ceased completely or at the $2 \sim 4$ nucleate stage. Once again, the effect was much more apparent in 'Pione' vines.

Table 4. Pollen tube growth in 'Pione' pistils grown on Nitsch media with different levels of NAA, GA and BA'

\begin{tabular}{|c|c|c|c|c|c|c|c|}
\hline \multirow{2}{*}{\multicolumn{2}{|c|}{ Phytohormones }} & \multicolumn{6}{|c|}{ Mean number of pollen tubes per pistily } \\
\hline & & \multicolumn{2}{|c|}{ Style } & \multicolumn{3}{|c|}{ Ovary } & \multirow{2}{*}{ Micropyle } \\
\hline & & Upper & Middle & Upper & Middle & Bottom & \\
\hline \multirow[t]{4}{*}{ NAA } & 0.01 & $10.6(8)$ & $3.3(4)$ & $1.5(2)$ & - & - & - \\
\hline & 0.1 & $8.7(12)$ & $2.5(3)$ & $1.0(1)$ & $1.0(1)$ & - & - \\
\hline & 1.0 & $12.5(10)$ & $4.3(5)$ & $2.0(3)$ & $1.0(1)$ & - & - \\
\hline & 10.0 & $8.5(5)$ & $1.0(2)$ & - & - & - & - \\
\hline \multirow[t]{4}{*}{$\mathrm{GA}$} & 0.01 & $10.3(9)$ & $3.7(5)$ & $2.5(3)$ & $1.5(2)$ & - & - \\
\hline & 0.1 & $7.3(11)$ & $2.4(6)$ & $2.0(2)$ & $1.0(1)$ & - & - \\
\hline & 1.0 & $15.6(12)$ & $1.5(4)$ & $1.0(2)$ & - & - & - \\
\hline & 10.0 & $11.3(9)$ & $1.7(3)$ & $1.0(1)$ & $1.0(1)$ & - & - \\
\hline \multirow[t]{4}{*}{$\mathrm{BA}$} & 0.01 & $8.2(7)$ & $2.5(6)$ & $1.5(2)$ & - & - & - \\
\hline & 0.1 & $10.5(8)$ & $3.7(5)$ & $2.0(1)$ & $1.0(1)$ & - & - \\
\hline & 1.0 & $7.4(6)$ & $1.0(2)$ & - & - & - & - \\
\hline & 10.0 & $5.3(3)$ & $1.3(4)$ & - & - & - & - \\
\hline Cont. & & $12.3(10)$ & $4.6(6)$ & $2.0(3)$ & $1.0(1)$ & - & - \\
\hline
\end{tabular}

" Each medium was added by $50 \mathrm{~g} / \mathrm{liter}$ of sucrose and $5 \mathrm{~g} / \mathrm{liter}$ of agar.

y Mean numbers only for the pistils where pollen tubes had reached. Figures in parentheses represent the number of pistils reached by pollen tubes among 15 pistils examined. - shows no pollen tube was found. 

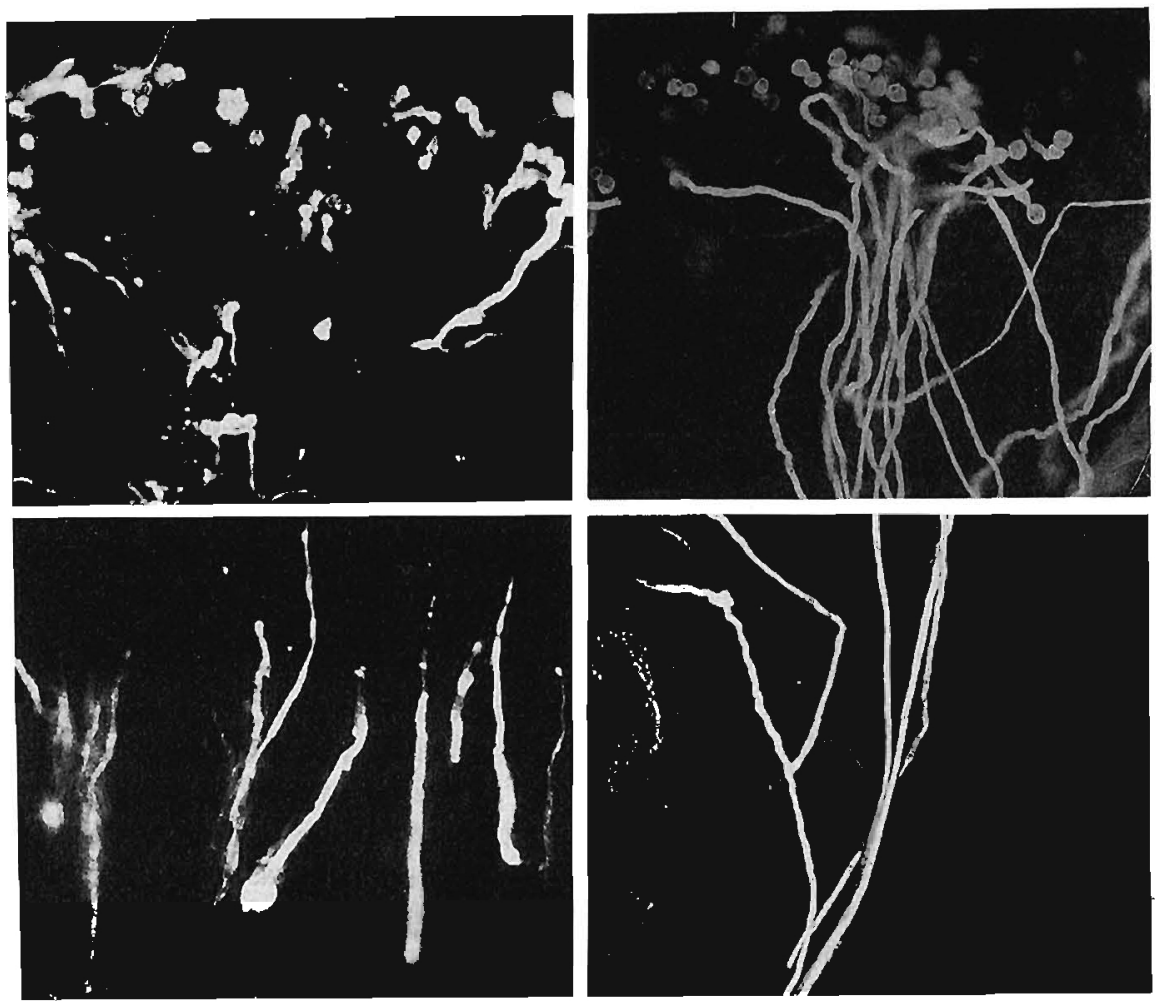

Fig. 2. Pollen tube growth in the style (upper) and in the ovary (lower) of 'Muscat of Alexandria' pistils cultured in vitro. Left: Water extracts from $0.5 \mathrm{~g}$ of 'Pione' pistils were added to $10 \mathrm{ml}$ of half-strength MS medium, Right: Control.

Spur-pruning of 'Pione' vines combined with pinching of vigorous shoot tips before bloom resulted in a greater increase in ovary size than cane-pruning of moderately vigorous vines without pinching. However, the percentage of normal embryo sacs in spur-pruned vines was reduced to about $20 \%(15,16)$, whereas the percentage of normal embryo sacs in cane-pruned vines was about $50 \%$. Imai et al. (1) reported that the restriction of the rooting volume of 'Pione' and 'Kyoho' cultivars resulted in a decrease in shoot length and ovary size at anthesis, but the number of ovules with normal embryo sacs was significantly increased. These results indicate that in tetraploid grape cultivars, if excessive amounts of inorganic nutrients are supplied to the flower cluster before anthesis, there is a reduction in the production of seeded berries because embryo sacs do not develop normally.
In 'Muscat of Alexandria', on the other hand, the number of perfect embryo sacs did not fall to $30 \%$ even when the concentration of inorganic nutrients was doubled in both Nitsch and MS media. As a common vineyard practice, shoot tips of this cultivar are pinched to ensure the set of seeded berries $(6,13)$.

Media containing a high concentration of inorganic nutrients inhibited pollen tube elongation at the base of the style of 'Pione' pistils, although any morphological or structural changes were not observed in the conductive tissue of the style. A high concentration of inorganic nutrients may produce a substance in the pistil that stops the growth of pollen tubes. Okamoto et al. (14) reported that in 'Kyoho', the mother plant of 'Pione', high amounts of alcohol-soluble nitrogenous compounds were found in the flower cluster of a pinched shoot. This may explain why pollen tube growth to the 
Table 5. Pollen tube growth in the pistil of 'Pione' and 'Muscat of Alexandria' grapes grown on the culture media containing pistil extracts.

\begin{tabular}{|c|c|c|c|c|}
\hline \multirow{3}{*}{\multicolumn{2}{|c|}{$\begin{array}{l}\text { Added pistil } \\
\text { extracts" }\end{array}$}} & \multicolumn{3}{|c|}{ No. of pollen tubes per pistily } \\
\hline & & \multirow{2}{*}{$\frac{\text { Style }}{\text { Upper }}$} & \multicolumn{2}{|c|}{ Ovary } \\
\hline & & & Upper & Lower \\
\hline \multicolumn{5}{|c|}{ Pione } \\
\hline \multicolumn{5}{|c|}{ Muscat } \\
\hline \multirow[t]{3}{*}{ of Alex. } & 0.1 & $10.2 \mathrm{NS}$ & $4.1 \mathrm{NS}$ & $1.1 \mathrm{NS}$ \\
\hline & 0.2 & $10.0 \mathrm{NS}$ & $2.0^{*}$ & $0.4 \mathrm{NS}$ \\
\hline & 0.5 & $10.8 \mathrm{NS}$ & $2.9 \mathrm{NS}$ & $0.6 \mathrm{NS}$ \\
\hline \multirow[t]{3}{*}{ Pione } & 0.1 & $9.0 \mathrm{NS}$ & $3.4 \mathrm{NS}$ & $1.5 \mathrm{NS}$ \\
\hline & 0.2 & $7.7 \mathrm{NS}$ & $1.3^{* *}$ & $0.3^{*}$ \\
\hline & 0.5 & $7.0^{*}$ & $1.7^{*}$ & $0.7 \mathrm{NS}$ \\
\hline \multicolumn{2}{|c|}{ Cont. } & 12.4 & 5.0 & 1.5 \\
\hline \multicolumn{5}{|c|}{ Muscat of Alexandria } \\
\hline \multirow[t]{3}{*}{$\begin{array}{l}\text { Muscat } \\
\text { of Alex. }\end{array}$} & 0.1 & $28.2 \mathrm{NS}$ & $14.7 \mathrm{NS}$ & $4.4 \mathrm{NS}$ \\
\hline & 0.2 & 43.3NS & $13.9 \mathrm{NS}$ & $5.4 \mathrm{NS}$ \\
\hline & 0.5 & $32.8 \mathrm{NS}$ & $8.4 \mathrm{NS}$ & $1.2^{*}$ \\
\hline \multirow[t]{3}{*}{ Pione } & 0.1 & $25.0 \mathrm{NS}$ & $10.2 \mathrm{NS}$ & $3.2 \mathrm{NS}$ \\
\hline & 0.2 & $19.7^{*}$ & $4.3^{*}$ & $1.0^{* *}$ \\
\hline & 0.5 & $18.5^{*}$ & $1.9^{* *}$ & $0.4^{* *}$ \\
\hline \multicolumn{2}{|c|}{ Cont. } & 36.1 & 12.6 & 7.0 \\
\hline
\end{tabular}

. Water extract from $0.1,0.2$ or $0.5 \mathrm{~g}$ of pistils were added to $10 \mathrm{ml}$ of $\times 1 / 2$ MS media.

$\checkmark$ Fifteen pistils were examined for each treatment. Means were compared with control, using t-test. ${ }^{*} ; 0.01<\mathrm{P}<0.05,{ }^{* *} ; \mathrm{P}<0.01$, NS; not significant.

Table 6. Pollen tube growth in the pistil of 'Muscat of Alexandria' grape grown on the media containing solvent fractions obtained from lyophilized water extracts of 'Pione' pistils.

\begin{tabular}{|c|c|c|c|c|c|}
\hline \multirow{3}{*}{\multicolumn{2}{|c|}{$\begin{array}{l}\text { Added solvent } \\
\text { extract }^{*}\end{array}$}} & \multirow{3}{*}{$\begin{array}{l}\text { No. of pistils } \\
\text { examined }\end{array}$} & \multicolumn{3}{|c|}{ No. of pollen tubes per pistily } \\
\hline & & & \multirow{2}{*}{$\frac{\text { Style }}{\text { Upper }}$} & \multicolumn{2}{|c|}{ Ovary } \\
\hline & & & & Upper & Lower \\
\hline \multirow[t]{3}{*}{ Hexane } & 0.25 & 12 & $15.6 \mathrm{NS}$ & $3.2 \mathrm{NS}$ & $1.5 \mathrm{NS}$ \\
\hline & 0.5 & 12 & $14.5 \mathrm{NS}$ & $3.5 \mathrm{NS}$ & $1.1 \mathrm{NS}$ \\
\hline & 1.0 & 12 & 19.1NS & $2.1 \mathrm{NS}$ & $0.1^{*}$ \\
\hline \multirow[t]{3}{*}{ EtOAc } & 0.25 & 12 & 13.1NS & $3.9 \mathrm{NS}$ & $0.4 \mathrm{NS}$ \\
\hline & 0.5 & 12 & $11.0 \mathrm{NS}$ & $2.7 \mathrm{NS}$ & $0.8 \mathrm{NS}$ \\
\hline & 1.0 & 12 & 8.0NS & $2.3 \mathrm{NS}$ & $1.1 \mathrm{NS}$ \\
\hline \multirow[t]{3}{*}{$\mathrm{EtOH}$} & 0.25 & 15 & $12.3 \mathrm{NS}$ & $2.5 \mathrm{NS}$ & $0.4 \mathrm{NS}$ \\
\hline & 0.5 & 15 & $7.2^{*}$ & $0.9^{*}$ & $0.2^{*}$ \\
\hline & 1.0 & 15 & $15.2 \mathrm{NS}$ & $1.1^{*}$ & $0.2^{*}$ \\
\hline \multirow[t]{3}{*}{$\mathrm{H}_{2} \mathrm{O}$} & 0.25 & 15 & $12.8 \mathrm{NS}$ & $3.5 \mathrm{NS}$ & $0.9 \mathrm{NS}$ \\
\hline & 0.5 & 15 & $7.3^{*}$ & $1.0^{*}$ & $0.0^{*}$ \\
\hline & 1.0 & 12 & $2.6^{* *}$ & $0.0^{* *}$ & $0.0^{*}$ \\
\hline \multicolumn{2}{|c|}{ Cont. } & 15 & 13.6 & 3.7 & 1.0 \\
\hline
\end{tabular}

" Each solvent extract from $0.25,0.5$ or $1.0 \mathrm{~g}$ of 'Pione' pistils was added to $10 \mathrm{ml}$ of $\times 1 / 2 \mathrm{MS}$ media.

"Means of each treatment were compared with control, using t-test. ${ }^{*} ; 0.01<\mathrm{P}<0.05,{ }^{* *}$; $\mathrm{P}<$ 0.01 , NS; not significant. 
base of the pistils was prevented.

Addition of $1 \sim 10 \mathrm{ppm}$ of BA, GA and NAA was seen to have controlling effect on the development of the embryo sac and the growth of the pollen tube. Germination and tube growth of grape pollen cultured on agar media were not prevented when less than $10 \mathrm{ppm}$ of $\mathrm{BA}$ or GA was added to the media (unpublished data). It is supposed that the prevention of pollen tube growth in the pistil on hormone media is due not to the effect of the actual hormones, but to some anatomical or chemical changes in the pistil.

The application of SADH to the flower cluster of 'Kyoho' improved the production of seeded berries (9). Naito et al. (11) found that GA activity in treated florets was lower and cytokinin activity was higher than in untreated ones. Komatsu (7) proposed that the reason why the rate of seeded berries is higher on hedge-trained vines of 'Kyoho' grapes than on trellised vines may be due to the low activity of GA in the flower clusters under the hedge system. However, why these hormonal conditions stimulate the production of seeded berries is yet unclear. When comparing the ovule development and pollen tube elongation of each cultivar on the media with different levels of GA, it was found that 'Muscat of Alexandria' was affected at a lower concentration than was 'Pione'. This trend is usually seen when GA is applied to the shoot or the flower cluster in vivo.

A water extract of pistils of tetraploid grapes prevents the germination of pollen and pollen tube growth on both liquid and agar media (18). When grape florets were cultured on media containing the water extract of pistils, the inhibitory effect on pollen tube growth in the pistil became visibly apparent. Pollen tube growth in the pistils of 'Muscat of Alexandria' was severely inhibited when pistils were cultured on a medium containing the aqueous extract of 'Pione' pistils. This indicates that the inhibitors contained in 'Pione' pistils also appear to act similarly in the pistils of other cultivars. The absorved inhibitors are apparently not metabolized or decomposed by the pistils. Okamoto et al. (19) found that the inhibitor is mainly composed of a low molecular substance which is nearly insoluble in hexane or ethyl acetate but is easily dissolved in alcohol and water. In our experiments with in vitro cultured pistils, we found that most of the inhibitory substances were detected in water soluble fractions. These substances were not found to affect the ovary size or ovule development. From these results it is concluded that this effect is caused by some substances that are not inorganic nutrients, i.e., nitrate or ammonium ions, or a hormone.

\section{Literature Cited}

1. Imai, S., G. Okamoto and M. Endo. 1987. Effects of dense planting and root-system control on attaining greater early production and fruit stability of tetraploid grapes. Bull. Hiroshima Fruit Tree Exp. Sta. $12: 1-9$. (In Japanese).

2. Inomata, N. 1968. In vitro culture of Brassica hybrids between $2 \mathrm{X}$ and $4 \mathrm{X}$. I. Culture medium. Japan. J. Breeding 18:17-26.

3. Ito, Y., H. Matui and N. Hirata. 1989. Growth and development of grape berries (cv. Kyoho) grown in in vitro culture. J. Japan. Soc. Hort. Sci. 58 (Suppl. 2) : 64-65.

4. Kano, Y. and T. Asahira. 1978. Effect of some plant growth regulators on the development of strawberry fruit in vitro culture. J. Japan. Soc. Hort. Sci. $47: 195-202$.

5. Kobayashi, A., H. Yukinaga and E. Matsunaga. 1965. Studies on the thermal conditions of grapes. V. Berry growth, yield and quality of Muscat of Alexandria as affected by night temperature. J. Japan. Soc. Hort. Sci. $34: 152-158$.

6. Kobayashi, A. and G. Okamoto. 1967. Effect of shoot pinching and boron spray on the nutrient content and berry set of Muscat of Alexandria. (I). J. Japan. Soc. Hort. Sci. $36: 31-35$. (In Japanese).

7. Komatsu, H. 1987. Studies on poor-berry setting of Kyoho grape. p. 83-95. Doctor Thesis, Osaka Pref. Univ. (In Japanese).

8. Murashige, T. and F. Skoog. 1962. A revised medium for rapid growth and bioassays with tabacco tissue cultures. Physiol. Plant. $15: 473-497$.

9. Naito, R., H. Ueda and T. Hayashi. 1974. Promotion of berry set in grapes by growth retardants. II. Effect of SADH and CCC applied directly to clusters on berry set and shoot growth in Kyoho and Muscat of Alexandria grapes. J. Japan. Soc. Hort. Sci. $43:$ 109-114.

10. Naito, R. and T. Hayashi. 1976. Promotion of berry set in grapes by growth retardants. III. Effects of prebloom application of SADH and CCC on gibberellin and cytokinin activity in florets of grape varieties, Kyoho and Muscat of Alexandria grapes. J. Japan. Soc. Hort. Sci. 45 : 135-142.

11. Naito, R. and T. Kawashima. 1980. Promotion of berry set in grapes by growth retardants. IV. 
Comparison of SADH cluster dipping, shoot pinching and flower thinning with regards to their effects on berry set in Kyoho grapes. J. Japan. Soc. Hort. Sci. 49 : 297-310.

12. Nitsch, J.P. 1951. Growth and development in vitro of excised ovaries. Am. J. Bot. $38: 566-576$.

13. Okamoto, G. and A. Kobayashi. 1971. Effect of shoot pinching and boron spray on the nutrient content and berry set of Muscat of Alexandria (II). J. Japan. Soc. Hort. Sci. $40: 212-224$. (In Japanese).

14. Okamoto, G., Y. Watanabe and K. Shimamura. 1980. Effect of topping and B-9 spray on the nutrition of cluster and berry setting in the vigorous shoot of Kyoho grape vine. Sci. Rep. Agri. Okayama Univ. 56:1-10. (In Japanese).

15. Okamoto, G., K. Yamamoto and K. Shimamura. 1984. A study of difference in the occurence of seedless berries among the tetraploid grapes related to Kyoho varieties. J. Japan. Soc. Hort. Sci. $53: 251-258$. (In Japanese).
16. Okamoto, G., Y. Nishimura and K. Shimamura. 1985. Promotion of seeded berry setting on the clusters of Pione grapes by cane pruning and B-9 spray on prebloom clusters. Sci. Rep. Agri. Okayama Univ. 66:1-7. (In Japanese).

17. Okamoto, G., M. Inoue and K. Shimamura. 1989. Effect of cross-pollination and several overcoming treatment for self-incompatibility on pollen tube growth in pistils of 'Pione' grapes. J. Japan. Soc. Hort. Sci. 58:311-317. (In Japanese).

18. Okamoto, G., I. Shibuya, M. Furuichi and K. Shimamura. 1989. Inhibition of pollen tube growth by diffusate and extract of grape pistils. J. Japan. Soc. Hort. Sci. $58: 515-521$. (In Japanese).

19. Okamoto, G., I. Shibuya and K. Shimamura. 1989. Properties of pollen tube growth inhibitors extracted from grape pistils. J. Japan. Soc. Hort. Sci. 58:523-528. (In Japanese).

20. White, P.R. 1963. The cultivation of animal and plant cells. p. 228. Ronald Press, New York.

In vitroにおけるブドウの子房の発育と花粉管生長に及ぼす無機塩, ホルモン，䧳ずい抽出物の影響

阙本五郎 · 大森直樹

岡山大学侲学部 700 岡山市津島

摘 要

ブドヴピオーネ’では, 胚珠の受精率が低いために有 核果が着生しにくい，この原因を探るために，開花約 1 週間前の小花を培羡し, 培地の归機塩, ホルモンお よび雌ずいの抽出物の添加滥度が胚珠の発育と受粉後 の花粉管生長に及ぼす影響を調查した，有核果が多く 着粒する‘マスカット・オブ・アレキサンドリア’を比較 の対照とした。

Nitsch あるいは MS 培地の無機塭岥度, Nitsch の培 地の空素紷度を高めると, 而品種とも子房の発育は促 されたが，胚のうの発育と受粉後の花粉管伸長は抑制 された.この傾向は特に゙ピオーネ’で著しかった. $1 〜 10$ ppm の GA, BA, NAA を添加すると, 子房の発育は 影響されなかったが, ‘ピオーネ’雌ずい内での胚のうの

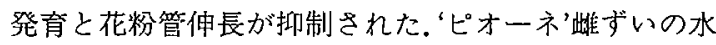
抽出物を培地に加之ると，雨品種とも子房および胚の うの発䏍は影㸉されなかったが，花柱内への花粉管伸 長が著しく抑制された。

以上のことから,'ピオーネ’の小花は窒素栄養の供給 が豊富であると，胚のうの発育と花粉管の生長が抑制 される。・ピオーネ’の泚ずいに多く含まれる花粉管生長 阻害物質は，無機物質やホルモン様物質とは異なるも のと思われる。 